\title{
Searching the Possibility of Electricity Production with Waste Heat Recovery from Iron and Steel Factory Sinter Cooler by ORC
}

\author{
Mehmet Ozkaymak ${ }^{*}$, Selcuk Selimli, Merve Ozturk, Ozlem Tutal, Seyda Ergin, \\ Tuba Arslan \\ Energy Systems Engineering, Technology Faculty, Karabuk University, Karabuk, Turkey
}

\begin{tabular}{ll}
\hline Article history & Requirement of energy in the life of humanity has been increasing \\
Received: & everyday more than one day before, but in the meantime energy \\
12.03 .2015 & sources have been running out rapidly. Efficient usage of energy is \\
Received in revised form: & sufficiently important for industrial facilities to resist the \\
14.04 .2015 & competitive conditions in the market by the reduction in cost of \\
& energy consumption and unit product cost. In this regard, waste \\
Accepted: & heat recovery potential during the ore cooling process at an iron \\
15.043 .2015 & and steel facility sinter plant by using ORC system was \\
Key words: & theoretically investigated. As a result, it is determined that about \\
Energy, efficiency, ORC. & 10\% of 9,527 kW waste power potential would be recovered to \\
& electricity in the industrial facility by the establishment of organic \\
& Rankine cycle (ORC). Environmentally, about 5001 tones CO $\mathrm{C}_{2} /$ year \\
& emission release by the combustion of coal to generate equal \\
& amount of electricity was eliminated by electricity generation by \\
& ORC. The payback period of the possible ORC system investment \\
& was foreseen about 2.4 years.
\end{tabular}

\footnotetext{
* Correspondence: 100. Yil Mah. Baliklar Kayasi Mevki, Karabuk University, Karabuk, Turkey, 78050, Tel: +90 370433 8202; Fax: +90 370433 8204. E-mail address: mozkaymak@karabuk.edu.tr
} 


\section{Introduction}

Most important input of the producers' capital is the energy. Increase in economic activity and production require the more energy consumption. Efficient usage of energy directly affects the costs in the market. Efficient consumption of the energy sustains the producers in the competitive sector. Efficient usage of energy is possible by energy efficient technologies, system enhancement and mostly the recovery of waste heat. More than $50 \%$ of generated total heat energy in industry is the low level heat and it is emitted in the range of 100 to $220^{\circ} \mathrm{C}$ [1]. The organic Rankine cycle can be used to recover low grade heat $\left(<250{ }^{\circ} \mathrm{C}\right)$ [2]. The $\mathrm{ORC}$ is the most popular one in these days to recover low temperature waste heat energy. Taking decision about waste recovery investment require the optimization of different parameters as the heat potential, cost, and sustainability. Khatita et al. (2014) studied the utilization of the ORC in an existing gas treatment plant, to recover the waste heat and convert it into electricity. The waste heat recovery using the organic Rankine cycle is a profitable process. The study shows that the payback period will not exceed 4 years. It is recommended that similar approach can be carried on other industries in order to contribute to energy saving and optimization [3]. Jung et al. (2014) investigated the technical and economic feasibility of converting waste heat from a stream of liquid kerosene. It was argued installation of a $250 \mathrm{~kW}$ ORC waste heat power converter on the kerosene cooling line would be technically feasible and economically viable [4]. Hammond and Norman (2014) were examined the various technologies to utilise the recovered heat. Greatest potential showed for heat use on-site and its conversion to electricity. The greatest potential for reusing this surplus heat was found to be recovery at low temperatures, utilising heat exchangers; and in conversion to electricity, mostly using organic Rankine cycle technology [5]. Zhiqi et al. (2012) analysed the performance of organic Rankine cycle system to recover low temperature waste heat from aluminium reduction cell. For heat source temperature between $150{ }^{\circ} \mathrm{C}$ and $170{ }^{\circ} \mathrm{C}$, R236fa gives the biggest net power and the corresponding net power ranges from $843 \mathrm{~kW}$ to $991 \mathrm{~kW}$. They argued that the net power is easily affected by the change of temperature. When the waste heat temperature decreases $10 \%$, the net power would deviate $30 \%$ from the nominal rating [6]. Wang et al. (2012) compared the effect of waste heat temperature and pinch point on the performance and economic characteristics of ORC system under the optimal conditions. They determined that decrease of heat source temperature, the value of payback period increases. When the heat source temperature is lower than $100{ }^{\circ} \mathrm{C}$, the ORC technology is inappropriate [7]. Zhou et al. (2013) constructed an experimental system for heat recovery from low-temperature flue gas based on organic Rankine cycle. The maximum cycle efficiency and net output power of expander are $8.5 \%$ and $645 \mathrm{~W}$ was determined [8].

Iron and Steel industry is in the class of the most energy intense facilities. In this aspect an industrial facility sinter plant waste heat recovery to produce electricity by ORC was investigated.

\section{Material and Method}

Studied sinter plant production capacity is approximately 1,200 tons/day. Suction area of the sinter is $110 \mathrm{~m}^{2}$. Cooling plant has 84 pallets and each has velocity is about $0.075 \mathrm{~m} / \mathrm{s}$. Pallets width is $3 \mathrm{~m}$. Fan flow rate is $0.158 \mathrm{~m}^{3} / \mathrm{s}$. Suction pressure is among 12 to $13 \mathrm{kPa}$. Rotary cooler has 16 bunkers. Two cooler air fans capacities are $111.112 \mathrm{~m}^{3} / \mathrm{s}$. Each fan redundantly operates. Blown air flows from central channel to bunker front panel, the air reachs the sinter internal region and cools down the sinter. Flow rate is regulated by operator due to the temperature requirement. Facility sinter plant was illustrated in Figure 1(a, b). 


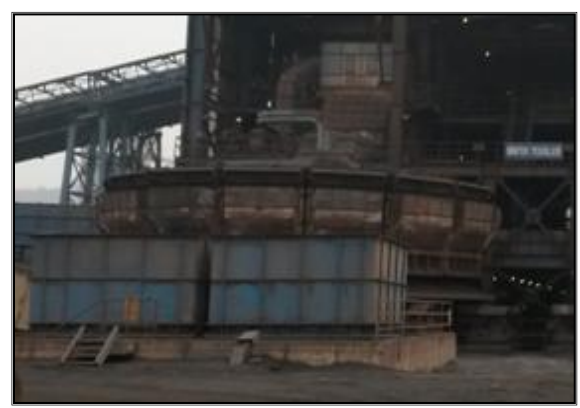

(a)

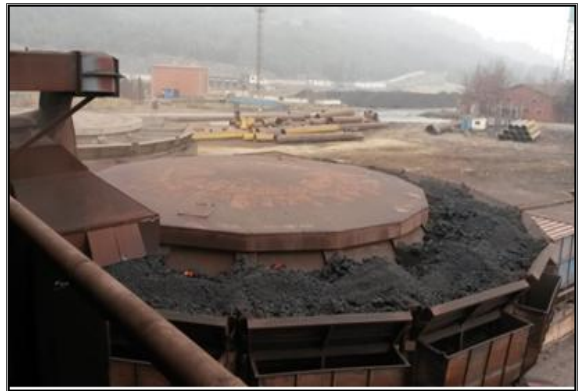

(b)

Figure 1(a, b). Studied sinter plant front and top view.

Estimated project was given in Figure 2.

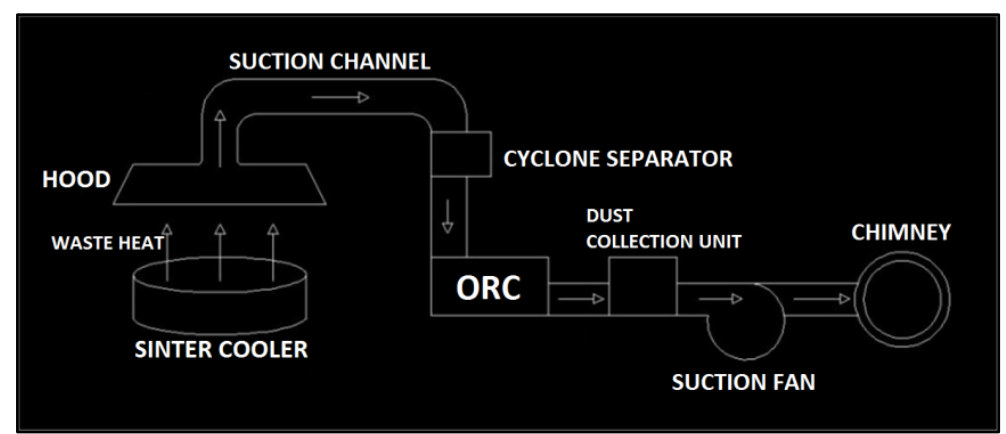

Figure 2. Schematic illustration of the project.

Evaluation of the Project required the temperature, the average temperature of it preparatory works at the sinter plant. In this was determined $350{ }^{\circ} \mathrm{C}$ and given in Figure aim, thermal measurements were done. 3. Thermal camera was used to measure the ore

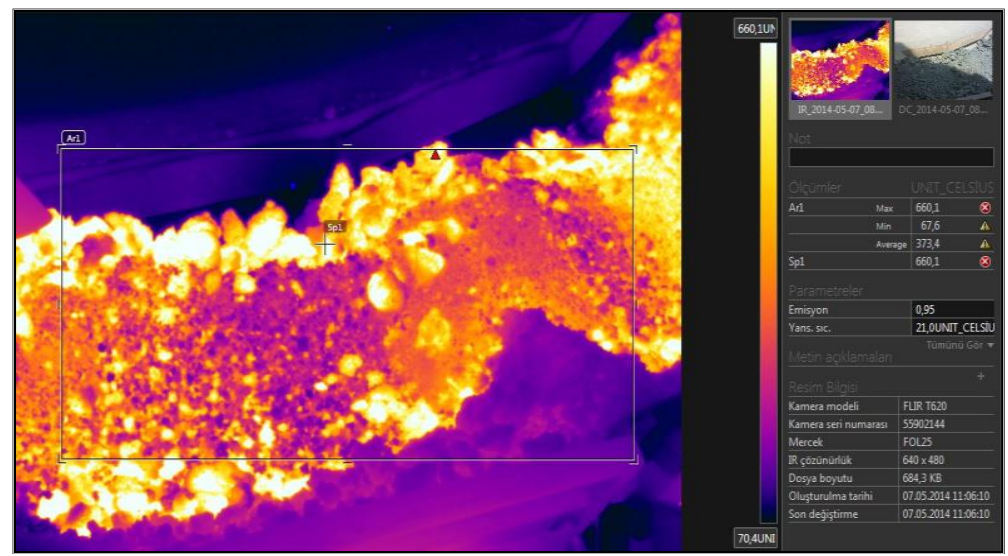

Figure 3. Thermal view of the ore temperature.

The wasted differential temperature was determined about $150{ }^{\circ} \mathrm{C}$. Usage of this 150 ${ }^{\circ} \mathrm{C}$ temperature waste heat to produce of electricity was theoretically investigated by Genetron software. Input parameters for the analysing software are determined as $150{ }^{\circ} \mathrm{C}$ evaporator air inlet temperature, $80{ }^{\circ} \mathrm{C}$ air exit temperature and $25{ }^{\circ} \mathrm{C}$ water inlet temperature. Air flow rate is about 111.112 $\mathrm{m}^{3} / \mathrm{s}$. 


\section{Results and discussion}

According to the system boundary conditions and assumed data. Possible waste heat source capacity was calculated as below;

Assumed air physical properties are $\rho_{\mathrm{a}}=1.225 \mathrm{~kg} / \mathrm{m}^{3}, \mathrm{c}_{\mathrm{p}}=1 \mathrm{~kJ} / \mathrm{kg} \mathrm{K}$

Amount of waste heat power potential was calculated in eq. (1);

$\mathrm{Q}=\dot{\mathrm{m}} \cdot \mathrm{c}_{\mathrm{p}} \cdot \Delta \mathrm{T}_{\mathrm{a}}=\dot{\mathrm{V}} \cdot \rho \cdot \mathrm{c}_{\mathrm{p}} \cdot \Delta \mathrm{T}_{\mathrm{a}}=111 \cdot 112 \times 1 \cdot 225 \times 1 \times(150-80) \approx 9,527 \mathrm{~kW}$

It is assumed that an amount of calculated waste power potential would be recovered by ORC. In the light of this assumption, Genetron software was used to estimate and simulate the ORC cycle. Optimum organic fluid had been estimated and efficiency of the system was determined. Efficiency value was used to calculate the possible theoretical electricity production potential. The system was simulated with software for different organic fluids are Butane, R245fa and Pentane. These fluids were chosen to study by taking into consideration of their critical temperature.

Simulation and performance evaluation resultant parameters of three different organic fluid was obtained from software user interface were given in Figure 4.

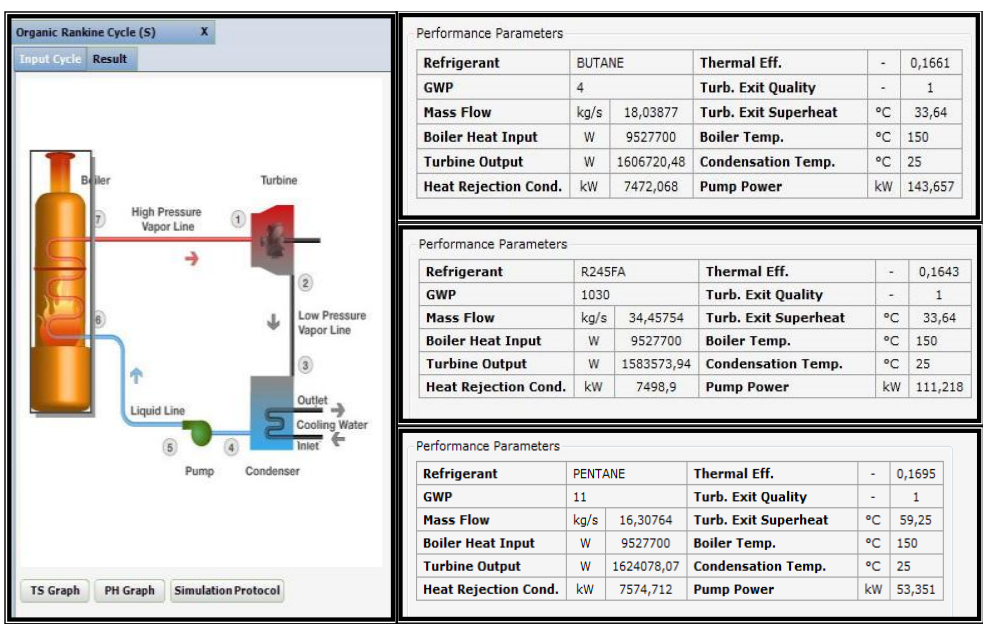

Figure 4. Software base organic fluids comparison visualization.

Analyses results estimated that the thermal efficiency of the system by using three different organic fluids are butane, R245fa and pentane is in the order as $16.61 \%, 16.43$ $\%$ and $16.95 \%$. As a result, it was shown that the most efficient ORC system was simulated by using pentane. The electricity production from the waste heat rate would be determined by adding the generator and fitting loses on $16.95 \%$. In this scope, assumed about $10 \%$ of this waste heat power potential could be turned into the electrical power in eq. (2).

$$
\mathrm{W}_{\mathrm{e}}=\eta \cdot \mathrm{Q}_{\mathrm{w}}=0.1 \times 9527=952.7 \mathrm{~kW} .
$$

The annual operation period of the system is about 6000 hours. 
Annual electrical energy production $=952.7 \times 6.000=5,716,200 \mathrm{kWh}$

Generated electricity selling cost is about 10.5 dollar cent $/ \mathrm{kWh}$.

Annual cost of saving $=5,716,200 \times 10.5=60,020,100$ dollar cent $=600,201 \$$

$1 \mathrm{MW}$ electricity production capacity system investment $\operatorname{cost}=1,442,307 \$$

Payback period of the investment $=1,442,307 / 600,201=2.4$ years .

Environmental positive impact of the waste heat recovery on the $\mathrm{CO}_{2}$ emission is another importance of the study. $\mathrm{CO}_{2}$ emissions coefficient of the coal-energy chain is

\section{Conclusion}

In this study, waste heat recovery potential during the ore cooling process at an iron and steel facility sinter plant by using ORC system was theoretically investigated. Software base estimations were done by Genetron Properties. Theoretical assumptions were considered and study was supported by ref. [6, 8]. Theoretical analyses results showed that $9,527 \mathrm{~kW}$ waste heat power could be turned into usable form. By using ORC system this usable energy was turned into about $952.7 \mathrm{~kW}$ electrical powers. 5001 tonnes/year $\mathrm{CO}_{2}$ emission release to produce equal amount of electrical energy from coal was eliminated. The payback period of the possible ORC system investment was foreseen about 2.4 years.

\section{References}

[1] Wang, Z.Q., Zhou, N.J., Guo, J. and Wang, X.Y., "Fluid selection and parametric optimization of organic Rankine cycle using low temperature waste heat", Energy, 40: 107-115 (2012).

[2] Walsh, C. and Thornley, P., "A comparison of two low grade heat recovery options", Appl. Therm. Eng., 53: 210-216 (2013).

[3] Khatita, M.A., Ahmed, T.S., Ashour, F.H. and Ismail, I.M., "Power generation using waste heat recovery by organic currently at $875 \mathrm{~g} / \mathrm{kWh}$ [9]. In this respect, annually about 5001 tonnes $\mathrm{CO}_{2}$ emission release was eliminated by the electricity generation by ORC.

Rankine cycle in oil and gas sector in Egypt: A case study", Energy, 64: 462472 (2014).

[4] Jung, H.C., Krumdieck, S. and Vranjes, T., "Feasibility assessment of refinery waste heat to-power conversion using an organic Rankine cycle", Energ. Convers. Manage., 77: 396-407 (2014).

[5] Hommand, G.P. and Norman, J.B., "Heat recovery opportunities in UK industry", Appl. Energ., 116: 387-397 (2014).

[6] Zhiqi, W., Naijun, Z. and Jing, G., "Performance analysis of ORC power generation system with low temperature waste heat of aluminium reduction cell", Phys. Procedia 24: 546-553 (2012).

[7] Wang, Z.Q., Zhou, N.J., Guo, J. and Wang, X.Y., "Fluid selection and parametric optimization of organic Rankine cycle using low temperature waste heat", Energy, 40: 107-115 (2012).

[8] Zhou, N., Wang, X., Chen, Z. and Wang, Z., "Experimental study on organic Rankine cycle for waste heat recovery from low-temperature flue gas", Energy, 55: 216-225 (2013).

[9] Yu, S., Wei, Y.M., Guo, H. and Ding, L., "Carbon emission coefficient measurement of the coal-to-power energy chain in China", Appl. Energ., 114: 290-300 (2014). 